\title{
FIRST RECORD OF Desmodus rotundus IN URBAN AREA FROM THE CITY OF OLINDA, PERNAMBUCO, NORTHEASTERN BRAZIL: A CASE REPORT
}

\author{
Filipe DANTAS TORRES(1), Carlos VALENÇA(2) \& Geraldo Vieira de ANDRADE FILHO(2)
}

\begin{abstract}
SUMMARY
The objective of this report is to describe the first record of Desmodus rotundus in urban area from the city of Olinda, Pernambuco State, Northeastern Brazil, and to draw attention to the possible risk of rabies transmission in this place. After the complaint of a dog owner who observed three bats attacking his dog, images registering attacks of $D$. rotundus were captured with a video camera. From 09:00 p.m. on 13 February 2004 to 04:00 a.m. of the next day, a high frequency of haematophagic activity and the presence of several bites on the dog's body were observed. This finding represents a serious risk to public health. Thus, it is necessary to further study the bat fauna, with special attention to their feeding behaviour in this place, in order to better know their biology and to adopt pertinent control measures. This is, to our knowledge, the first record of $D$. rotundus in urban area of Olinda.
\end{abstract}

KEYWORDS: Common vampire bat; Urban area; Olinda; Northeastern Brazil.

Haematophagous bats, also called vampire bats, occur only in Latin America, from Mexico to the Northern Argentina and are represented by three species: Desmodus rotundus, Diphylla ecaudata and Diaemus youngi (Phyllostomidae). Only D. rotundus, the common vampire bat, causes livestock losses and could be a vector for the rabies virus ${ }^{1,3}$.

Dogs, humans, zoo animals and small backyard animals are potential food sources for haematophagous bats in urban areas ${ }^{10}$. All reports of outbreaks of human aggression and human rabies caused by vampire bats are related to activities of $D$. rotundus ${ }^{2}$.

The common vampire bat plays an important role in the transmission of rabies to humans in several countries ${ }^{4}$, including Brazil $^{3,7}$. Thus, the presence of this bat in urban areas must be seen as a potential risk to public health.

Several species of bats were described in Brazil ${ }^{5,6,8,10}$, but few researchers dedicated theirs studies to the bat fauna of Pernambuco state, Northeastern Brazil, mainly in municipalities of the metropolitan region of Recife.

This report's objective is to describe the occurrence of $D$. rotundus in urban area from the city of Olinda, Pernambuco State, Brazil, and to draw attention to the possible risk of rabies transmission in this place.

In February 2004, attacks of bats to a male Doberman dog were communicated by a dog owner who had two more dogs and lives in a house located in a residential urban area of Olinda. The city $\left(8^{\circ} 00^{\prime} 48^{\prime \prime} \mathrm{S}\right.$ $34^{\circ} 50^{\prime} 42^{\prime \prime} \mathrm{W}$ ) has a tropical climate with an average annual temperature of $27{ }^{\circ} \mathrm{C}$, annual relative humidity of $80 \%$, and annual precipitation between 1,000 and $2,000 \mathrm{~mm}$. The house is located next to a small reserve of primary Atlantic rain forest.

From 09:00 p.m. on 13 February 2004 to 04:00 a.m. of the next day, the attacks of bats were captured in the house with the help of a video camera (JVC S-VHS Compact Camcorder, type GR-SXM337UM).

The images showed the individual attacks of the bats with morphological characteristics ${ }^{1}$ and feeding behaviour ${ }^{9}$ compatible with D. rotundus (Figs. 1 and 2). It was observed a rather long thumb and forearm, dark brown fur on the back and body with approximately 90 $\mathrm{mm}$ of length.

A total of nine attacks from the bats were witnessed. In addition, the number and the distribution of bites on the dog's body (scrotum, lombar and perianal region and feet) suggested feeding activity of several bats. However, it was not possible to estimate the number of bats.

Skin lesions due to previous exposure to bat bites and also new lesions were observed. Bites on the limbs and anal region were found, showing an unusual feeding activity.

The attacks occurred only when the dog was sleeping and the bats were not seen on the dog's body but only while landing on the floor. Thus, this finding shows that there is an evidence of the existence of a D. rotundus population adapted to feed on dogs. 

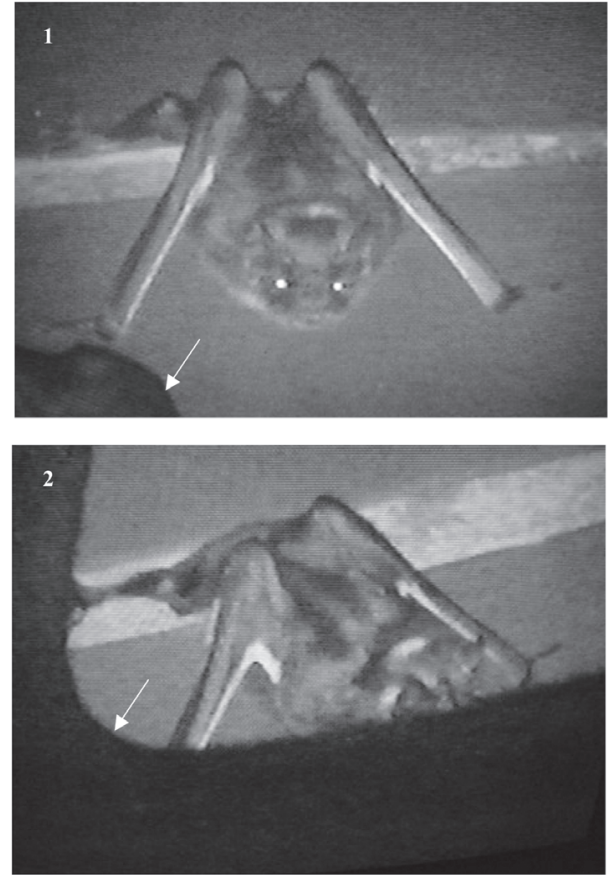

Figs. 1 and 2 - (1) An individual of Desmodus rotundus next to the dog (arrow). (2) The same individual feeding on the dog (arrow).

Other domestic animals, like chickens and goats, were observed in that place. Probably, these animals are also acting as sources of food to common vampire bats although we did not obtain reliable data to confirm this hypothesis.

To our knowledge, this is the first report of $D$. rotundus in the urban area of Olinda, although its presence in urban areas was already reported by UIEDA ${ }^{10}$ in the cities of São Paulo (State of São Paulo), Rio de Janeiro (State of Rio de Janeiro), Belo Horizonte (State of Minas Gerais) and Salvador (State of Bahia). Fortunately, there is no evidence of bat attacks on humans in this place. Moreover, the dog was revaccinated against rabies.

Vampire bats are the second major rabies transmitter to humans ${ }^{4}$. Thus, it is necessary to investigate the rabies virus infection in this bat population from the city of Olinda, to evaluate the potential risk of rabies virus transmission to humans and dogs.

Finally, it is also important to study the bat fauna, with special attention to their feeding behaviour in this place, in order to improve our knowledge of their biology, mainly of haematophagous bats, and to adopt pertinent control measures.

\section{RESUMO}

Primeiro registro de Desmodus rotundus na área urbana da cidade de Olinda, Pernambuco, Nordeste do Brasil: relato de caso

O objetivo deste relato é descrever o primeiro registro de Desmodus rotundus na área urbana da cidade de Olinda, estado de Pernambuco,
Nordeste do Brasil, e chamar atenção para o possível risco de transmissão da raiva nesta localidade. Após a queixa de um proprietário que observou três morcegos atacando um de seus cães, foram capturadas imagens com auxílio de uma câmara de vídeo que registram ataques de $D$. rotundus ao referido cão. No período das 21:00h do dia 13 de fevereiro de 2004 às 4:00h da manhã do dia seguinte, foram observados nove ataques de $D$. rotundus e também a presença de mordidas em várias partes do corpo do cão. Esse achado representa um sério risco para saúde pública. Conseqüentemente, faz-se necessária a realização de novos estudos a fim de conhecer melhor a biologia desta população de morcegos, com atenção especial para o comportamento alimentar, e adotar as medidas de controle pertinentes. Este é, para o nosso conhecimento, o primeiro relato da presença de $D$. rotundus em área urbana de Olinda.

\section{ACKNOWLEDGEMENTS}

The authors would like to thank Cultura Inglesa, especially to Alberto Costa and Ellen Smith for their help. To the referees for their helpful comments on the manuscript.

\section{REFERENCES}

1. EISENBERG, J.F. \& REDFORD, K.H. - Mammals of the neotropics. The central neotropics: Ecuador, Peru, Bolivia, Brazil. Chicago, University of Chicago, 1999. v. 3, 610p.

2. GONÇALVES, M.A.S.; SÁ-NETO, R.J. \& BRAZIL, T.K. - Outbreak of aggressions and transmission of rabies in human beings by vampire bats in northeastern Brazil. Rev. Soc. bras. Med. trop., 35: 461-464, 2002.

3. MAYEN, F. - Haematophagous bats in Brazil, their role in rabies transmission, impact on public health, livestock industry and alternatives to an indiscriminate reduction of bat population. J. Vet. Med. Series B, 50: 469-472, 2003.

4. ORGANIZACIÓN PANAMERICANA DE LA SALUD - Vigilancia epidemiológica de la rabia en las Américas. Rio de Janeiro, Centro Panamericano de Fiebre Aftosa, 2001.

5. PEDRO, W.A. \& TADDEI, V.A. - Bats from southwestern Minas Gerais, Brazil (Mammalia: Chiroptera). Chiroptera Neotrop., 4: 85-88, 1998.

6. REIS, N.R.; PERACCHI, A.L.; LIMA, I.P.; SEKIAMA, M.L. \& ROCHA, V.J. - Updated list of the Chiroptera of the city of Londrina, Paraná, Brazil. Chiroptera Neotrop., 4: 96-98, 1998.

7. SCHNEIDER, M.C.; DE ALMEIDA, G.A.; SOUZA, L.M.; DE MORARES, N.B. \& DIAZ, R.C. - Controle da raiva no Brasil de 1980 a 1990. Rev. Saúde publ. (S. Paulo), 30: 196-203, 1996.

8. SILVA, M.M.; HARMANI, N.M.S.; GONÇALVES, E.F.B. \& UIEDA, W. - Bats from the Metropolitan Region of São Paulo, Southeastern Brazil. Chiroptera Neotrop., 2: 39-41, 1996.

9. UIEDA, W. - Biologia e dinâmica populacional de morcegos hematófagos. In: CURSO DE ATUALIZAÇÃO EM RAIVA DOS HERBÍVOROS, 2., Curitiba, 1996. Anais. p. 63-87.

10. UIEDA, W. - The common vampire bat in urban environments from Southeastern Brazil. Chiroptera Neotrop., 1: 22-24, 1995.

Received: 29 April 2004

Accepted: 2 December 2004 